\title{
Bazı Pamuk Çeşitlerinin ISSR Markörleri İle Karakterizasyonu
}

\author{
Cenk Burak ŞAHIN ${ }^{1}$, Necmi İŞLER $^{2}$, Vafa RUSTAMOVA ${ }^{3}$ \\ ${ }^{1,2}$ Hatay Mustafa Kemal Üniversitesi, Ziraat Fakültesi, Tarla Bitkileri Bölümü, Antakya, Hatay, ${ }^{3}$ The Genetic Resources Institute of the \\ Azerbaijan National Academy of Sciences, Bakü, Azerbaycan \\ ${ }^{1}$ https://orcid.org/0000-0001-6270-8184, ${ }^{2}$ https://orcid.org/0000-0001-5877-7830, ${ }^{3}$ https://orcid.org/0000-0001-8765-2551 \\ $\bowtie$ : cbsahin@mku.edu.tr
}

\section{ÖZET}

Bu çalışmada, kültürü yapılan 30 pamuk çeşidi (Gossypium hirsutum L.) arasındaki genetik ilişkinin ISSR yöntemi kullanılarak belirlenmesi hedeflenmiştir. Otuz pamuk çeşidinde polimorfizmin belirlenmesi amaciyla 24 ISSR primeri 8 pamuk çeşidinde test edilmiştir. Primerlerin yalnızca 9 tanesi PCR ürünü oluşturmuş ve sonraki çalışmalar bu primerlerle sürdürülmüştür. Seçilen 9 adet ISSR primeri 30 adet pamuk çeşidinde toplam 41 bant oluştururken bu bantlardan ortalama 22.3 tanesinin polimorfik olduğu saptanmış, primer başına polimorfik bant sayısı ortalama 2.5 olarak gerçekleşmiştir. Araştırmada kullanılan tüm primerler pamukta polimorfik bant üretirken, polimorfizm oranı primerlere bağlı olarak \%6 ile \%89 arasında değişim göstermiştir. ISSR primerlerine ilişkin polimorfik bilgi içeriği değerleri 0.19 ile 0.68 aralığında değişim göstermiş ve ortalama 0.49 olmuştur. Ceşitler arası ortalama Jaccard benzerlik katsayısı 0.77 olarak bulunurken, UPGMA kümeleme analiz sonucu 30 pamuk çeşidi genetik yakınlık açısından 2 ana kümeye ayrılmıştır.

\section{Characterization of Some Cotton Varieties Using ISSR Markers}

\section{ABSTRACT}

This study was conducted to determine the genetic diversity in 30 cotton (Gossypium hirsutum L.) cultivars extensively cultivated in Turkey by using ISSR DNA molecular markers. To investigate the genetic diversity in 30 cotton varieties by ISSR molecular marker, 24 ISSR primers were screened in 8 varieties. Overall, 9 of 24 which produced a PCR product were selected according their polymorphism level. These ISSR primers totally produced 41 bands, and 22.3 were polymorphic. The percentage of polymorphic bands per primer was detected as 2.5 . The rate of polymorphism depending on the primers ranged between $6 \%$ and $89 \%$. Average polymorphism information content was 0.49 , with minimum PIC 0.19 and maximum PIC 0.68. While the Jaccard similarity coefficient between the genotypes was detected as $0.77,30$, cotton varieties were grouped within two main clusters in respect to genetic similarity based on UPGMA analyses.

\section{Araştırma Makalesi}

Makale Tarihçesi

Geliş Tarihi : 20.05 .2019

Kabul Tarihi : 05.07.2019

\section{Anahtar Kelimeler \\ Pamuk, \\ Gossypium hirsutum L., \\ Genetik çeşitlilik, \\ ISSR}

\section{Research Article}

$\begin{array}{ll}\text { Article History } & \\ \text { Received } & : 20.05 .2019 \\ \text { Accepted } & : 05.07 .2019\end{array}$

\section{Keywords}

Cotton,

Gossypium hirsutum L.,

Genetic diversity,

ISSR

To Cite : Şahin CB, İşler N, Rustamova V 2020. Bazı Pamuk Çeşitlerinin ISSR Markörleri İle Karakterizasyonu. KSÜ Tarım ve Doğa Derg 23 (1): 108-116. DOI: 10.18016/ksutarimdoga.vi.567725.

\section{GíRIŞ}

Pamuk, gerek Türkiye'de gerekse de dünyada tekstil sanayinin en önemli hammaddelerindendir. Pamuk, lifi yanında gıda ve yem ürünlerinin üretimi için yetiştirilen önemli bir bitkidir (Mert, 2009). Türkiye'de 2007-2016 yılları arasinda ortalama 500 bin ha alandan; ylllk ortalama 1.3 milyon ton pamuk (çiğit+kütlü+lif) üretimi gerçekleşmiştir (TÜİK, 2018). Ülkemiz, dünya pamuk üretimi sıralamasında Çin, Hindistan, ABD, Pakistan, Brezilya, Özbekistan ve
Avustralya'nın arkasından 8. sirada yer almaktadır (FAO, 2018).

Elektroforetik analizler genetik kaynaklara ulaşılmasında, genotipler arası farkların gösterilmesinde oldukça güçlü ve ucuza mal olan tekniklerdir ve özellikle gelişmekte olan ülkelerde direkt DNA veya RNA seviyelerindeki çalışmalardan ziyade bu yöntemin tercih edilmesi daha avantajlıdır. Ayrıca bu yöntemler bize; sayısı gittikçe artan çeşitlerin saflığını göstermek, çeşitler arası tanımlama 
yapmak, genetik çeşitlilik hakkındaki bilgileri arttırarak evrime destek sağlamak konularında da yardımcı olur (Peirce ve Brewbaker, 1973; Gorman ve Kiang, 1977; Cardy ve Beversdorf, 1984; Hamrick ve ark. 1991; Sammour, 1991).

Morfolojik ve biyokimyasal markırların (işaretleyicilerin) yerine son zamanlarda çeşitlerin karakterizasyonunda DNA işaretleyicileri kullanılmaya başlanmıştır. Bitkiler arasındaki genetik ilişkileri ortaya çıkarmak için ilk olarak RFLP yöntemi kullanılmıştır (Tanksley ve ark., 1989). Fakat bu yöntem kısa sürede çok örneğin incelenmesine olanak sağlamadığından ve maliyetinin çok yüksek olmasindan dolayı, PCR'a dayalı moleküler işaretleyicilerin ortaya çıkmasına neden olmuştur. RAPD, AFLP, SSR ve ISSR teknikleri, kültür bitkilerinde genetik çeşitliliğin saptanmasında yoğun olarak kullanılmaktadır. Çalışlacak laboratuvar olanakları göz önünde bulundurulduğunda; RAPD, SSR ve ISSR tekniklerinin radyoaktif madde kullanımının olmadığı ve araştırma koşullarının sinirlı olduğu laboratuvarlarda rahatlıkla kullanılabilecek yöntemler olduğu bildirilmiştir (Belaj ve ark., 2003; Mignouna ve ark., 2003; Rana ve Bhat, 2004; Kwon ve ark., 2004).

Pamuk tür ve çeşitlerini DNA düzeyinde belirlemek için birçok moleküler yöntem kullanılmıştır (Pillay ve Myers, 1999; Chaudhary ve ark. 2010; Hussein ve ark. 2006). RFLP, pamukta tür ve çeşit ayrımında genom haritalamalarında uzun yıllar oldukça etkili bir yöntem olarak uygulanmıştır (Reinisch ve ark. 1994). Ancak RFLP'de DNA'larin enzim ile kesilme gerekliliği, radyoaktif esaslı olması, uygulamadaki zorluğu ve pahalılığı alternatif bir metot olan PCR esaslı RAPD moleküler tekniğinin geliştirilmesine neden olmuştur (Williams ve ark., 1990). Zietkiewicz ve ark. (1994) tarafından geliştirilen dinükleotid, tetranükleotid ve pentanükleotid tekrar dizilerine dayanan bazlara sahip primerlerin kullanıldığı, uygulama maliyetinin diğer yöntemlere nazaran düşük olduğu, genotipleri birbirinden ayırma gücünün ise yüksek olması özelliğiyle bilinen ISSR tekniği; pamuk ve birçok kültür bitkisinde tür içi ve türler arası genetik çeşitliliğin tespit edilmesinde başarıyla kullanılmıştır (Liu ve Wendel, 2001).

Erkılınç ve Karaca (2005) yaptıkları çalışmada, 36 Türk pamuk çeşidinde 25 çift SSR primeri kullanarak çeşitler arasındaki genetik farklılığı belirlemeye çalışmışlardır. SSR analizi sonucunda toplam 32 bant oluşmuş ve 25 primer çiftinden sadece 4 primer çifti polimorfik bant vermiştir. Oluşturulan dendrogramda 36 çeşit 3 ana gruba ayrılmıştır. Araştırmacılar, çalışma sonunda Türk pamuk çeşitlerinde genetik çeşitliliğin çok düşük olduğunu ve yeni çeşitlerin geliştirilmesi için yeni germplazmların bulunmasının gerektiğini vurgulamışlardır.

Bardak ve Bolek (2012), Dünyanın farklı bölgelerinde yetiştiriciliği yapılan diploid ve tetraploid 25 pamuk genotipi (Gossypium spp.) arasındaki genetik ilişkiyi belirlemek için 5 ISSR ve 39 SSR primeri kullanmıştır. Elde edilen 173 allelden 155 tanesinin (\%89.60) polimorfik olduğu bildirilmiştir. Primer başına 3.93 allel düşmüştür. Polimorfik bilgi içeriği (PIC) değeri 0.0040 ile 0.9993 arasında değişirken, ortalama PIC değeri 0.4396 bulunmuştur. Bütün genotipler arasındaki genetik çeşitlilik oranı 0.04 ile 0.58 arasındadır. $\mathrm{Bu}$ oran, G. hirsutum L. genotipleri arasinda 0.04-0.23, G. barbadense L. genotipleri arasında 0.07-0.26 ve diğer türler arasında 0.23-0.57 arasında değişmiştir. Gen havuzundaki çeşitliliği artırmak için yabani pamuk türlerinin kullanımı önerilmiş ve arzu edilen özelliklerin seçiminde faydası olacağı belirtilmiştir.

Bu çalışma, Türkiye'de geliştirilen 30 pamuk çeşidinin ISSR yöntemi kullanarak genetik benzerlik ve farklılıklarını ortaya koymak ve çeşit geliştirme çalışmalarında ıslah programlarının planlanmasına yönelik kaynak sağlamak amacıyla yürütülmüştür.

\section{MATERYAL ve METOT}

Araştırmada materyal olarak, Türkiye'deki farklı Üniversiteleri ile Tarımsal Araştırma Enstitülerince geliştirilip tescil ettirilmiş, tamamı tetraploid Gossypium hirsutum L. (2n=4x=52, AADD) türüne ait, farklı ekolojilerde yaygın olarak yetiştiriciliği yapılmış ve halen yapılmakta olan 30 ticari pamuk çeşidi kullanılmıştır. Çoğunluğu melezleme, bazıları ise seleksiyon ıslahı ile geliştirilmiş olan çeşitler ile köken bilgileri Çizelge 1'de verilmiştir.

\section{DNA İzolasyonu}

Hem liyofilizatörde kurutulan hem de $-80^{\circ} \mathrm{C}$ 'de stoklanan örneklerden DNA eldesi, Doyle ve Doyle (1987) tarafından bildirilmiş olan CTAB mini izolasyon yöntemi uygulanarak gerçekleştirilmiştir.

Liyofilizatörde kurutulan örneklerden DNA izolasyonu: Örnekler 2 ml'lik eppendorf tüplere konularak üzerine $0.9 \mathrm{ml}$ CTAB DNA izolasyon çözeltisi eklenmiştir. Her 15 dakikada bir elle nazikçe çalkalamak koşuluyla, $65^{\circ} \mathrm{C}$ 'de 1 saat 10 dakika süre ile su banyosunda bekletilmiştir. Su banyosundan çıkarılan örnekler bir süre soğumaya bırakılmış ve daha sonra $0.9 \mathrm{ml}$ kloroform:isoamilalkol (1:24) karışımı eklenerek yine elle bir süre (1-2 dakika), daha sonra çalkalayıcı üzerinde, düşük hızda yavaşça 15 dakika çalkalanmıştır. Daha sonra tüpler 15 dakika süre ile 13000 rpm'de santrifüj edilmişlerdir. Santrifüj edilen tüplerin üst fazları mikropipetle alınarak 2 ml'lik yeni eppendorf tüplere aktarılmıştır. Bu tüplerin üzerine $600 \mu \mathrm{l}$ isopropanol eklenmiş ve elle yavaşça alt üst yapılıp tek faz haline getirilerek DNA'nın çökelmesi sağlanmıştır. Bu aşama sonrasinda tüpler $-20^{\circ} \mathrm{C}^{\prime}$ de 1 saat bekletilmiş ve 
DNA'ların tam çökelmeleri temin edilmiştir. Derin dondurucudan çıkarılan eppendorf tüplerinden, DNA dipte kalacak şekilde tüm sıvı dökülmüş ve $0.9 \mathrm{ml}$ Amonyum Asetat eklenerek yavaş devirde 15 dakika çalkalayıcıda çalkalanmıştır. Daha sonra 10000 rpm'de kısa süreli santrifüj yapılmış ve içerisindeki sıvı dikkatli şekilde dökülmüştür. Örnekler kuruması için bir gece bekletilmiştir.

Çizelge 1. Araştırmada kullanılan pamuk (G. hirsutum L.) çeşitleri ve kökenleri (TTSM, 2018)

Table 1. Cotton (G. hirsutum L.) varieties and origins used in the research (TTSM, 2018)

\begin{tabular}{|c|c|}
\hline Çeşidin Adı (Varieties) & Tescil Ettiren Islahçı Kuruluş (Registrant) \\
\hline ADN P01 & Doğu Akdeniz Tarımsal Arş. Enst. Müd. \\
\hline Aydin-110 & Pamuk Araştırma İstasyonu Müdürlüğü \\
\hline Ayhan 107 & Pamuk Arastırma İstasyonu Müdürlüğü \\
\hline Barut 2005 & Pamuk Araştırma İstasyonu Müdürlüğü \\
\hline Coşkun-1 & Pamuk Araştırma İstasyonu Müdürlüğü \\
\hline Dicle 2002 & GAP Uluslararası Tarımsal Araștırma ve Eğitim Mer. Müd. \\
\hline GAPEYAM-1 & GAP Tarımsal Araştırma Enstitüsü Müdürlüğü \\
\hline Gossypolsüz 86 & Ege Üniversitesi Ziraat Fakültesi \\
\hline Gürelbey & Pamuk Araştırma İstasyonu Müdürlüğü \\
\hline Menderes 2005 & Pamuk Araştırma İstasyonu Müdürlüğü \\
\hline Nazilli 143 & Pamuk Araştırma İstasyonu Müdürlüğü \\
\hline Nazilli $84 \mathrm{~S}$ & Pamuk Araştırma İstasyonu Müdürlüğü \\
\hline Nazilli M-342 & Pamuk Araştırma İstasyonu Müdürlüğü \\
\hline Sayar 314 & Doğu Akdeniz Tarımsal Araştırma Enstitüsü Müd. \\
\hline Şahin-2000 & Pamuk Araştırma İstasyonu Müdürlüğü \\
\hline Çukurova 1518 & Doğu Akdeniz Tarımsal Araştırma Enstitüsü Müd. \\
\hline Adana 98 & Doğu Akdeniz Tarımsal Araştırma Enstitüsü Müd. \\
\hline Özbek 142 & Pamuk Araştırma İstasyonu Müdürlüğü \\
\hline Nazilli M39 & Pamuk Araştırma İstasyonu Müdürlüğü \\
\hline Nazilli 663 & Pamuk Araştırma İstasyonu Müdürlüğü \\
\hline Nazilli 66-100 & Pamuk Araştırma İstasyonu Müdürlüğü \\
\hline Nazilli 342 & Pamuk Araştırma İstasyonu Müdürlüğü \\
\hline Maraş-92 & Doğu Akdeniz Geçit Kuşağı Tarımsal Araş. İstasyonu Müd. \\
\hline Erşan-92 & Doğu Akdeniz Geçit Kuşağı Tarımsal Araş. İstasyonu Müd. \\
\hline Nazilli 954 & Pamuk Araştırma İstasyonu Müdürlüğü \\
\hline Ekşi 911 & Pamuk Araştırma İstasyonu Müdürlüğü \\
\hline Nazilli 87 & Pamuk Araştırma İstasyonu Müdürlüğü \\
\hline Ege 69 & Pamuk Araştırma İstasyonu Müdürlüğü \\
\hline Nazilli M 503 & Pamuk Araştırma İstasyonu Müdürlüğü \\
\hline Nazilli 303 & Pamuk Araştırma İstasyonu Müdürlüğü \\
\hline
\end{tabular}

$-80^{\circ} \mathrm{C}$ 'de bekletilen örneklerden DNA izolasyonu: Alüminyum folyo içerisinde laboratuvara getirilen örnekler sıvı azot dolu bir kaba konulmuştur. Yaprak örnekleri sırasıyla havanlara alınarak öğütülmüş ve 2 ml'lik eppendorf tüplere alınmıştır. Artan örnekler tekrar alüminyum folyoya sarılarak $-80^{\circ} \mathrm{C}^{\prime}$ ye konulmuştur. Tüplerdeki örneklerin üzerine $0.9 \mathrm{ml}$ CTAB DNA izolasyon çözeltisi eklenmiştir. Önceki bölümde kuru örnekler için yapılan izolasyon işlemleri aynı şekil ve sıra ile bu örnekler için de tekrarlanmış ve DNA izolasyonu gerçekleştirilmiştir.

Tüm bu işlemler sonrasında yapılan gözlemler kuru örneklerden, yaş örneklere nazaran daha temiz DNA elde edilebildiğini ortaya koymuştur.

İzolasyon sonucu elde edilen DNA'ların miktarını tayin etmek için \%0.8'lik agaroz jel kullanılmıştır. İlk üç kuyuya sırasıyla $5 \lambda, 10 \lambda$ ve $20 \lambda$ DNA markörleri ve sonrasına ise çeşitlere ait DNA örnekleri gelecek şekilde 10'ar $\mu \mathrm{l}$ yüklenmiştir. Agaroz jele yüklenen DNA'lar 130 voltta 30 dakika koşturulmuştur. İşlem sonrasında jel çıkartılarak küvete alınmış ve jelin üstüne çıkacak şekilde etidyum bromür konulmuştur. Jelin yırtılmaması, tahrip olmaması için çalkalayıcının hızı düşük seviyede 5 dakika çalkalanmıştır. Sonrasında saf su eklenmiş ve durulanması için tekrar aynı hı ve sürede çalkalanmıştır. UV transilluminatör yardımıyla jel görüntüsünde gözlemlenen DNA yoğunlukları $\lambda$ DNA'lar (5 ng-10 ng-20 ng) ile karşlaştırılarak belirlenmiş ve her bir çeşit örneği için elde edilen DNA miktarı saptanmıştır.

Hesaplanan DNA miktarlarına göre PCR analizi için DNA konsantrasyonları $\mu$ l'de $10 \mathrm{ng} / \mathrm{ug}$ olacak şekilde ultra saf su ile seyreltilmiş ve yeniden jelde koşturulmuştur. $\mathrm{Bu}$ şekilde, her örneğin DNA miktarının 10 ng'a gelmesi sağlanmıştır. Jel hazırlama ve DNA koşturma işlemleri aynen tekrarlanmış ve jel 
görüntülenmiştir. Görüntü sonucunda DNA'ların istenen düzeye geldiği saptanmış ve sonraki işlemlerin liyofilize edilen kuru örneklerden elde edilen DNA'lar ile yürütülmesine karar verilmiştir.

\section{Araştırmada Kullanılan Primerler}

Araştırmada, DNA'ya yapışma sıcaklı̆ğ daha önce yapılmış çalışmalarda belirlenmiş olan 24 adet primer screening (çalışacak-çalışmayacak primerlerin belirlenmesi) yapmak üzere, polimorfizm bakımından test edilmiştir. Seçilen primerler ve DNA'ya yapışma sıcaklıkları Çizelge 2'de verilmiştir.
Primerleri polimorfizm bakımından test etmek amacıyla 8 çeşit seçilmiştir. Analiz sonucunda 9 primerin polimorfizm oluşturduğu saptanmış ve çalışmaların bu primerler ile devam ettirilmesi kararlaştırılmıştır.

\section{PCR Reaksiyonları ve Elektroforez}

PCR amplifikasyonu işlemi için reaksiyon her bir tüp, $2 \mu$ l genomik DNA, $1 \mathrm{ml}$ dNTPs, $1 \mathrm{ml}$ primer, $18.3 \mathrm{ml}$ ddH2O, $2.5 \mathrm{ml}$ Green Buffer, $0.18 \mathrm{ml}$ DreamTaq olacak şekilde hazırlanmıştır. PCR amplifikasyonunda kullanılan primerler, baz dizilişi ve sayıları Çizelge 3 ’te verilmiştir.

Çizelge 2. Screening yapılan primerlerin nükleotid dizilimleri ve DNA yapışma sıcaklıkları

Table 2. Nucleotide sequences and DNA binding temperatures of screened primers

\begin{tabular}{|c|c|c|c|c|c|}
\hline $\begin{array}{l}\text { Primer } \\
\text { İsimleri } \\
\text { Primers }\end{array}$ & $\begin{array}{l}\text { Yapışma } \\
\text { Sicaklıkları }\left({ }^{\circ} \mathrm{C}\right) \\
\text { Binding } \\
\text { Temperatures }\left({ }^{\circ} \mathrm{C}\right)\end{array}$ & $\begin{array}{l}\text { Nükleotid } \\
\text { Dizileri } \\
\text { Nucleotide } \\
\text { Sequences } \\
\end{array}$ & $\begin{array}{l}\text { Primer } \\
\text { İsimleri } \\
\text { Primers }\end{array}$ & $\begin{array}{l}\text { Yapışma } \\
\text { Sicaklıkları }\left({ }^{\circ} \mathrm{C}\right) \\
\text { Binding } \\
\text { Temperatures }\left({ }^{\circ} \mathrm{C}\right)\end{array}$ & $\begin{array}{l}\text { Nükleotid } \\
\text { Dizileri } \\
\text { Nucleotide } \\
\text { Sequences } \\
\end{array}$ \\
\hline UBC811 & 52 & (GA)8C & UBC835 & 54 & (AG) $8 \mathrm{YC}$ \\
\hline UBC 823 & 52 & (TC) $8 \mathrm{C}$ & UBC844 & 54 & (CT) 8RC \\
\hline UBC826 & 52 & (AC) $8 \mathrm{C}$ & UBC841 & 54 & (GA) $8 \mathrm{YC}$ \\
\hline UBC827 & 52 & (AC) $8 \mathrm{G}$ & A105ISSR02 & 54 & (TG) $9 \mathrm{~T}$ \\
\hline UBC 836 & 52 & (AG) 8YA & A112ISSR04 & 54 & $\mathrm{AG}(\mathrm{GT}) 8 \mathrm{~T}$ \\
\hline B116ISSR02 & 52 & (AC) 8TAA & B116ISSR04 & 54 & (AC) $9 \mathrm{~T}$ \\
\hline B108ISSR02 & 52 & (TC) $7(\mathrm{AC}) 2$ & B108ISSR05 & 54 & $\mathrm{~T}(\mathrm{CA}) 9$ \\
\hline UBC809 & 52 & (AG) $8 \mathrm{G}$ & B108ISSR03 & 54 & (TC) $7(\mathrm{AC}) 2 \mathrm{~A}$ \\
\hline UBC852 & 52 & (TC) $8 \mathrm{RA}$ & A217ISSR01 & 54 & $\mathrm{~A}(\mathrm{AG}) 7(\mathrm{GT}) 2$ \\
\hline UBC858 & 52 & (TG) $8 \mathrm{RT}$ & A005ISSR01 & 54 & (TG) $9 \mathrm{~A}$ \\
\hline UBC855 & 52 & (AC) $8 \mathrm{YT}$ & A005ISSR04 & 54 & (TG) 8(TA) 2 \\
\hline UBC 840 & 52 & (GA) 8YT & A110ISSR03 & 54 & $\mathrm{~A}(\mathrm{GT}) 9$ \\
\hline
\end{tabular}

Çizelge 3. Kullanılan primerler, baz diziliş ve sayıları ile DNA yapışma sıcaklıkları

Table 3. Base sequences, numbers and binding temperatures of primers

\begin{tabular}{llll}
\hline $\begin{array}{l}\text { Primer İsimleri } \\
\text { Primers }\end{array}$ & $\begin{array}{l}\text { Primer Baz Dizileri 5' } \rightarrow 3^{\prime} \\
\text { Base Sequences 5' } \rightarrow \text { 3' }\end{array}$ & $\begin{array}{l}\text { Baz Sayısı } \\
\text { Number of bases }\end{array}$ & $\begin{array}{l}\text { Yapışma Sicaklıkları }\left({ }^{\circ} \mathrm{C}\right) \\
\text { Binding Temperatures }\left({ }^{\circ} \mathrm{C}\right)\end{array}$ \\
\hline UBC 827 & ACA CAC ACA CAC ACA CG & 17 & 52 \\
UBC 836 & AGA GAG AGA GAG AGA GYA & 18 & 52 \\
UBC 855 & ACA CAC ACA CAC ACA CYT & 18 & 52 \\
UBC 835 & AGA GAG AGA GAG AGA GYC & 18 & 54 \\
UBC 841 & GAG AGA GAG AGA GAG AYC & 18 & 54 \\
UBC844 & CTC TCT CTC TCT CTC TRC & 18 & 54 \\
A105ISSR02 & (TG)3C(GT)6 & 19 & 54 \\
B108ISSR05 & T(CA)9 & 19 & 54 \\
A110ISSR03 & A(GT)9 & 19 & 54 \\
\hline
\end{tabular}

Genomik DNA'nın çoğaltımı için PCR reaksiyonları, thermocycler (Eppendorf Mastercycler Gradient) cihazında yürütülmüştür. PCR döngü ve sicaklık koşulları; 1 . Adım- $94^{\circ} \mathrm{C}^{\prime}$ de 2 dakika 1 döngü, 2 . Adım$94^{\circ} \mathrm{C}^{\prime}$ de 1 dakika, $52^{\circ} \mathrm{C}^{\prime}$ de (ve $\left.54^{\circ} \mathrm{C}^{\prime} \mathrm{de}\right) 1$ dakika, $72^{\circ} \mathrm{C}^{\prime} \mathrm{de}$ 2 dakika 40 döngü ve 3 . Adım- $72^{\circ} \mathrm{C}^{\prime}$ de 10 dakika olacak şeklinde programlanmıştır.

PCR reaksiyonu sonrasinda amplifikasyon ürünleri $\% 1.8$ 'lik agaroz jelde 150 voltta 3 saat koşturulmuştur. Bant büyüklüklerinin belirlenmesinde $\lambda$ DNA'nın
EcoRI ve HindIII kesim enzimleri ile hazırlanmış olan DNA standart markör olarak kullanılmıştır. Elektroforez işlemi sonrasında jel etidyum bromür ile boyama işlemi gerçekleştirilmiş, saf su ile durulanmış ve UV transilluminatör yardımı ile görüntülenmiş ve fotoğraflanmıştır.

\section{Verilerin Değerlendirilmesi}

Çeşitler arasındaki genetik benzerlik ve genetik uzaklık değerleri, ISSR bantlarının polimorfik olup 
olmamasına göre varlığında 1 , yokluğunda 0 olacak şekilde sinıflandırılarak hazırlanmış olan veri matrisinden yararlanarak Nei ve Li (1979) tarafindan geliştirilen benzerlik oranı formülüne göre hesaplanmış ve genetik uzaklık matrisi elde edilmiştir. Çoğaltılan her ISSR primeri için polimorfizm bilgi içeriği (PIC) PowerMarker V 3.25 paket programı yardımı ile hesaplanmıştır. Genetik benzerlik indeksi Jaccard'a göre hesaplanmış ve NTSYS-version 2.0 istatistik paket programinda UPGMA (Unweighted pair-group method arithmetic average) gruplandırmasına göre çeşitlere ait dendrogram elde edilmiştir.

\section{BULGULAR ve TARTIŞMA}

Pamuk (G. hirsutum L.) çeşitlerinde genetik çeşitliliği ortaya koyabilmek amaciyla öncelikle polimorfik olabilecek ISSR primerlerini saptamak üzere 8 pamuk çeşidinde 24 ISSR primeri test edilmiştir. Test sonucunda PCR ürünü meydana getiren 9 ISSR primeri belirlenmiş ve 30 pamuk çeşidinde moleküler analizler bu primerler ile devam ettirilmiştir. Jel görüntülerinin işlenmesi neticesinde, tüm çeşitler için oluşan toplam bant sayıları ile elde edilen polimorfik bant sayıları ve polimorfizm oranı değerleri Çizelge 4'te verilmiştir. Çizelgeden görüleceği gibi kullanılan 9 adet ISSR primerinin 30 adet pamuk çeşidinde, 41 bant oluşturduğu ve bu bantlardan ortalama 22.3 tanesinin polimorfik olduğu görülmüştür. Primer başına polimorfik bant sayısı ortalama 2.5 bulunmuştur.

Polimorfizm oranları açısından primerler kıyaslandığında en yüksek polimorfizm oranının 0.89 ile A110ISSR03 ISSR primerinden elde edildiği görülmektedir. En düşük polimorfizm ise A105ISSR02 primerinde (0.06) saptanmıştır. Öte taraftan diğer bazı primerlerde de polimorfizm oranı düşük olmakla beraber, kullanılan tüm primerlerin pamukta polimorfik bant üretebildikleri, polimorfik bant oranının \%6 ile \%89 arasında değiştiği gözlenmiştir.

İncelenen çeşitler arasında polimorfik (allel farklılıkları) farklılıkların oranının oldukça yüksek olduğu görülmektedir. Bu durum seçilen primerlerin daha önceden test edilerek çeşitler arasında polimorfik bant oluşturduğu tespit edilmiş olanlardan seçilmesi, çalışmada da polimorfizm oranını artırmıştır.

Araştırmada kullanılan primerlerin baz dizilimleri, baz sayıları ve polimorfik bilgi içeriği değerleri Çizelge 5 'te verilmiştir. Polimorfik bilgi içeriği (PIC) incelendiğinde; en yüksek PIC değerinin 0.68 ile UBC 836 primerinden, en düşük PIC değerinin ise 0.19 ile UBC 841 primerinden elde edildiği görülmüştür. Ortalama PIC değeri ise 0.49 olarak hesaplanmıştır.

ISSR DNA markör verileri kullanılarak $G$. hirsutum L. çeşitleri arasında Jaccard (1908) yöntemine göre Jaccard benzerlik katsayı değerleri hesaplanmıştır. Ortalama Jaccard benzerlik katsayısı 0.77 olarak bulunmuştur. Jaccard benzerlik katsayısına göre $G$. hirsutum L. çeşitleri birbirleriyle karşılaştırıldığında, genetik bazda en yakın Nazilli 303 çeşidinin 0.20 benzerlik katsayısı ile Erşan-92 ve Gapeyam-1 çeşitleri ile, Nazilli 66-100 çeşidinin yine 0.20 benzerlik katsayısı ile Gapeyam-1 çeşidi ile genetik yakınlık gösterdiği saptanmıştır. Genetik bazda en uzak çeşitler için benzerlik katsayısı ise 1.41 olarak belirlenmiştir. ISSR verileri kullanılarak NTSYS paket programı yardımı ile Nei (1972)'ye göre yapılan UPGMA (Unweighted Pair Group With Arithmetic Average) kümeleme analiz sonucu Şekil 1'de verilmiştir.

Çizelge 4. ISSR Primerlerinin Amplifikasyonu Sonucu Elde Edilen Toplam Bant Sayıları, Polimorfik Bant Sayıları ve Polimorfizm Oranları

Table 4. Total Band Counts, Polymorphic Band Counts and Polymorphism Rates Obtained by Amplification of ISSR Primers

\begin{tabular}{llll}
\hline $\begin{array}{l}\text { Primer İsimleri } \\
\text { Primers }\end{array}$ & $\begin{array}{l}\text { Toplam Bant Sayıs } \\
\text { Total Bands }\end{array}$ & $\begin{array}{l}\text { Ortalama Polimorfik } \\
\text { Bant Saylsı } \\
\text { Average Number of Polymorphic } \\
\text { Bands }\end{array}$ & $\begin{array}{l}\text { Polimorfizm Oranı } \\
\text { Polymorphism Rates }\end{array}$ \\
\hline UBC 827 & 5 & 2.4 & 0.48 \\
UBC 836 & 5 & 3.3 & 0.65 \\
UBC 835 & 6 & 1.2 & 0.19 \\
UBC 841 & 5 & 2.4 & 0.49 \\
UBC 844 & 3 & 2.6 & 0.88 \\
UBC844 & 3 & 2.2 & 0.72 \\
A105ISSR02 & 4 & 0.2 & 0.06 \\
A110ISSR03 & 6 & 5.3 & 0.89 \\
B108ISSR05 & 4 & 2.7 & 0.68 \\
\hline Toplam & 41 & 22.3 & 0.56 \\
Sum & & & \\
\hline
\end{tabular}


Çizelge 5. ISSR primelerinin nükleotid dizilimi ve PIC (polimorfik bilgi içeriği) değerleri

Table 5. Nucleotide sequence and PIC (polymorphic information content) values of ISSR primers

\begin{tabular}{llcc}
\hline $\begin{array}{l}\text { Primer İsimleri } \\
\text { Primers }\end{array}$ & $\begin{array}{l}\text { Primer Dizileri 5'-3' } \\
\text { Base Sequences 5' } \rightarrow \text { 3 }\end{array}$ & $\begin{array}{c}\text { Baz Sayıs } \\
\text { Number of bases }\end{array}$ & $\begin{array}{c}\text { PIC Değerleri } \\
\text { PIC }\end{array}$ \\
\hline UBC 827 & ACA CAC ACA CAC ACA CG & 17 & 0.61 \\
UBC 836 & AGA GAG AGA GAG AGA GYA & 18 & 0.68 \\
UBC 835 & ACA CAC ACA CAC ACA CYT & 18 & 0.62 \\
UBC 841 & AGA GAG AGA GAG AGA GYC & 18 & 0.19 \\
UBC 844 & GAG AGA GAG AGA GAG AYC & 18 & 0.50 \\
UBC844 & CTC TCT CTC TCT CTC TRC & 18 & 0.40 \\
A105ISSR02 & (TG)3C(GT)6 & 19 & 0.48 \\
A110ISSR03 & T(CA)9 & 19 & 0.43 \\
B108ISSR05 & (GT) 9 & 19 & 0.48 \\
\hline Ortalama (Average) & & & 0.49 \\
\hline
\end{tabular}

Elde edilen dendrogram haritası ise Şekil 2'de görülmektedir. Her iki şekilden de görüleceği üzere 30 pamuk çeşidi genetik yakınlık açısından 2 ana kümeye ayrılmıştır. Ana kümenin birinde ADN P01, Nazilli 342 ve Nazilli 143 çeşitleri yer almıştır. Diğer ana küme ise iki alt kümeye, alt kümelerden biri ise kendi içerisinde tekrar ikiye ayrılmıştır. Nitekim, Erkılınç ve Karaca (2005)'nın yaptığı çalışmada olduğu gibi Ege 69 ile Nazilli 66-100, Nazilli M503 ile Maraş 92, Nazilli 87 ile Nazilli 84S çeşitleri aynı alt kümelerde yer almıştır. Ek olarak, Bardak ve Bolek (2012)'in yaptığı çalışma ile benzeşen sonuçlar bulunmaktadır. Sayar 314,
Erşan 92 ve Maraş 92 çeşitleri bu çalışmada aynı küme içerisinde yer almıştır.

Sonuç olarak; ISSR moleküler DNA tekniği analizinde UBC 827, UBC 836, UBC 835, UBC 841, UBC 844, UBC844, A105ISSR02, A110ISSR03 ve B108ISSR05 primerleri kullanarak ticari pamuk çeşitlerinin DNA bazında birbirlerinden ayrılabileceği, ISSR tekniğinin ucuz, kolay ve tekrarlanabilir özelliğinden dolayı bir dominant marker olarak olanakları kısıtlı laboratuvarlarda kolaylıkla uygulanabileceği sonucuna varılmıştır.

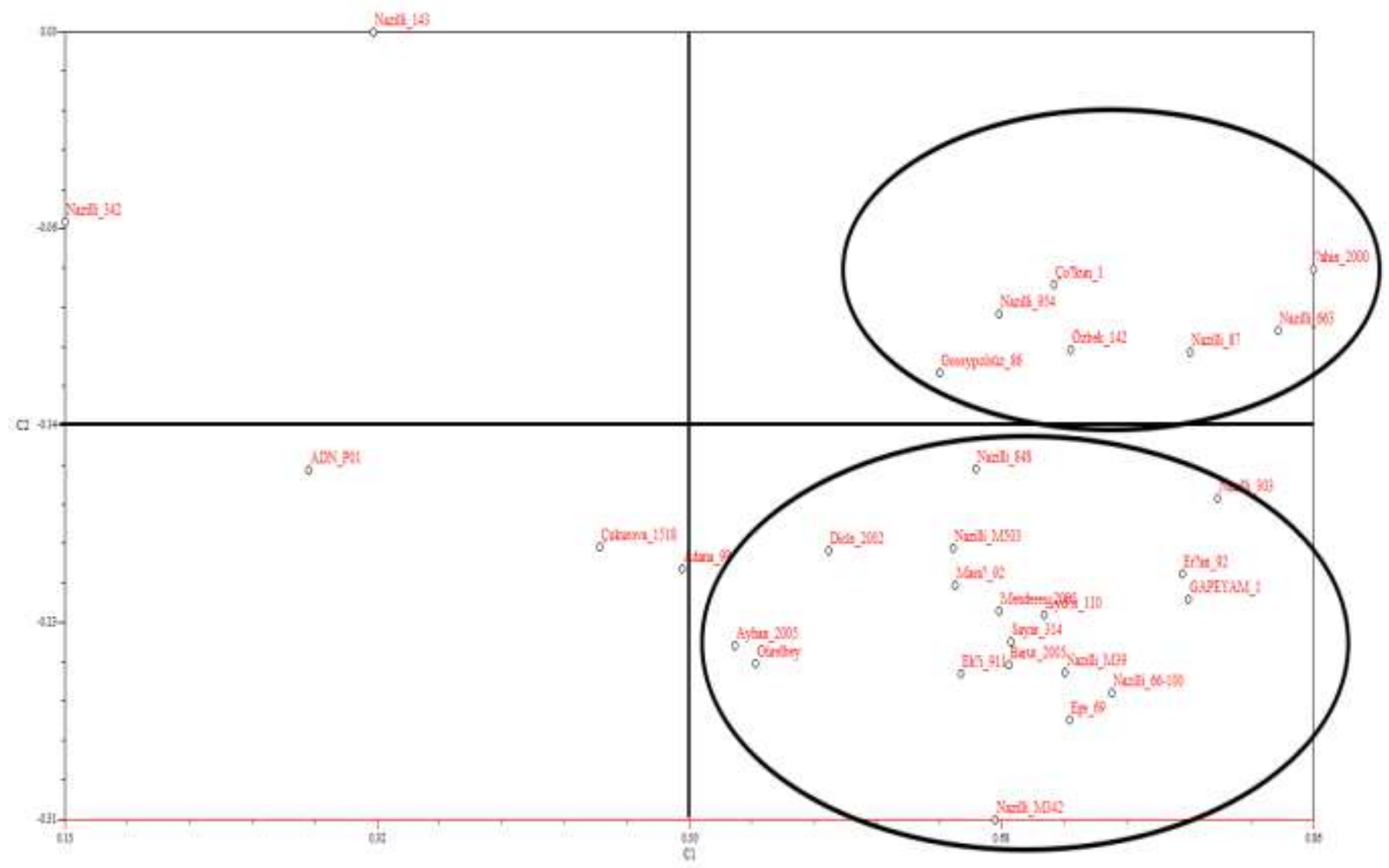

Şekil 1. ISSR verileri kullanılarak hazırlanan kümeleme analizi Figure 1. Clustering analysis using ISSR data 


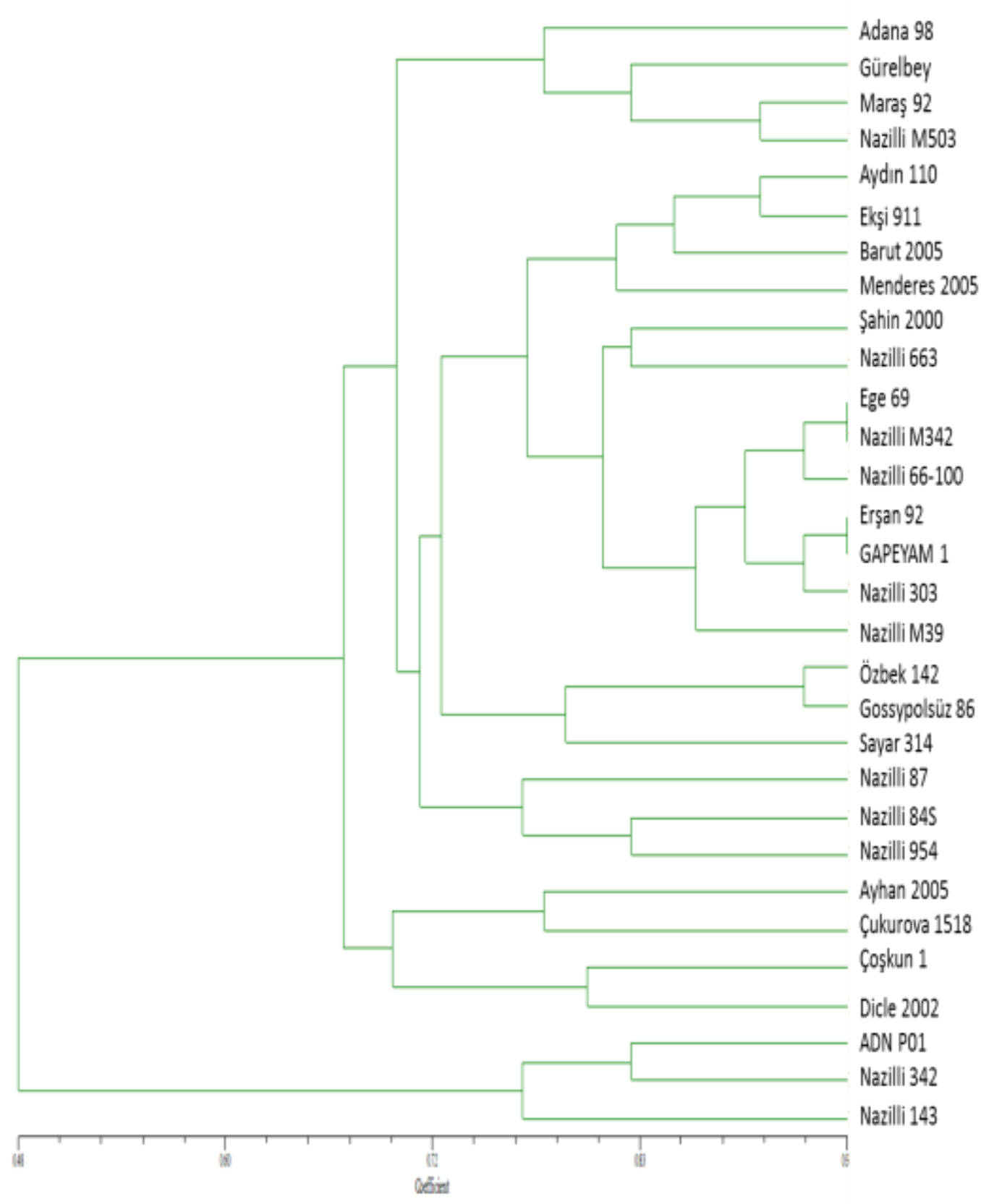

Şekil 2. ISSR verileri kullanılarak UPGMA metoduna göre çizilen genetik benzerlik dendrogram Figure 2. Genetic similarity dendrogram plotted according to UPGMA method using ISSR data

\section{SONUÇ}

Bu araştırmada 30 pamuk (Gossypium hirsutum L.) çeşidi genetik benzerlikleri DNA seviyesinde ISSR DNA markörü yardımıyla belirlenmiştir. Elde edilen sonuçlar kısaca aşağıda özetlenmiştir.

1. Çeşitleri DNA seviyesinde ayırmak için ilk önce 24 ISSR primer 8 pamuk çeşidinde ön araştırmada kullanılmış olup, bunlardan 9 adedinin PCR ürünü meydana getirdiği, 15 ISSR primerinin bir ürün meydana getirmediği saptanmıştır.

2. Kullanılan 9 adet 9 ISSR primerinin 30 adet pamuk çeşidinde, 41 bant oluşturduğu ve bu bantlardan ortalama 22.3 tanesinin polimorfik olduğu saptanmıştır. Primer başına polimorfik bant sayısı ortalama 2.5 olarak bulunmuştur.

3. Polimorfizm oranları açısından primerler kıyaslandığında en yüksek polimorfizm oranı 0.89 ile A110ISSR03 ISSR primerinde elde edilirken, en düşük polimorfizm ise A105ISSR02 primerinde saptanmıştır.

4. Kullanılan tüm primerlerin pamukta polimorfik bant üretebildikleri, polimorfik bant oranının \%6 ile \%89 arasında değiştiği belirlenmiştir.

5. ISSR primerlerine ilişkin polimorfik bilgi içeriği (PIC) değerleri 0.19 ile 0.68 aralığında değişim göstermiştir. 
6. En yüksek polimorfik bilgi içeriği (PIC) olan 0.68 değeri UBC 836 primerinde, en düşük PIC değeri ise 0.19 ile UBC 841 primerinden elde edilmiş ve tüm primerler için ortalama PIC değeri ise 0.49 olarak hesaplanmıştır.

7. Ortalama Jaccard benzerlik katsayısı 0.77 olarak bulunmuştur.

8. Jaccard benzerlik katsayısına göre Nazilli 303 çeşidinin 0.20 benzerlik katsayısı ile Ersan -92 ve Gapeyam-1 çeşitleri ile en yakın benzerlik gösterdiği, Nazilli 66-100 çeşidinin yine 0.20 benzerlik katsayısı ile Gapeyam-1 çeşidi ile genetik yakınlık içinde olduğu saptanmıştır. Genetik bazda en uzak çeşitler için benzerlik katsayısı ise 1.41 olarak belirlenmiştir.

9. UPGMA kümeleme analiz sonucu 30 pamuk çeşidi genetik yakınlık açısından 2 ana kümeye ayrılmıştır. Ana kümenin birinde ADN P01, Nazilli 342 ve Nazilli 143 çeşitleri yer alırken diğer ana küme de iki alt kümeye, alt kümelerden biri ise kendi içerisinde yine tekrar iki alt kümeye ayrılmıştır.

10.ISSR moleküler markör tekniğinin pamukta genetik çeşitliliği belirleme çalışmalarında başarıyla uygulanabileceği, bununla birlikte göstermiş olduğu yüksek polimorfizm ve tekrarlanabilme özelliğinden dolayı, laboratuvar olanakları kısıtlı birçok laboratuvarda başarıyla uygulanabileceği sonucuna varılmıştır.

\section{TEŞEKKÜR}

Yardımları ve destekleri için Prof.Dr. Nafiz ÇELIKKTAŞ, Dr.Öğr.Üyesi Yaşar AKIŞCAN ve Prof.Dr. Hakan ÖZKAN'a teşekkür ediyoruz. Bu çalışma, Cenk Burak ŞAHINN'in yüksek lisans tezinden üretilmiştir. Çalışmanın özeti, "1st International Eurasian Conference on Biological and Chemical Sciences (EurasianBioChem'18)" kongresinde poster bildiri olarak sunulmuştur.

\section{Çıkar Çatışması Beyanı}

Makale yazarları aralarında herhangi bir çıkar çatışması olmadığını beyan ederler.

\section{Araştırmacıların Katkı Oranı Beyan Özeti}

Yazarlar makaleye eşit oranda katkı sağlamış olduklarını beyan ederler.

\section{KAYNAKLAR}

Bardak A, Bolek Y 2012. Genetic diversity of diploid and tetraploid cottons determined by SSR and ISSR markers. Turkish Journal of Field Crops, 17(2):139144

Belaj A, Satovic Z, Cdpriani G, Baldoni L, Testolev R., Rallo L, Trujtllo I 2003. Comparative study of the discriming capacity of RAPD, AFLP and SSR markers and of their effectiveness inestablishing genetic relationships in olive. Theoretical and Applied Genetics, 107(4): 736-744.

Cardy BJ, Beversdorf WD 1984. A procedure for the starch gel electrophoretic detection of isozymes in soybean [Glycine max (L.) Merr.]. Dep. Crop Sci. Tech. Bull 119/8401. Univ. of Guelph, Ontario, Canada.

Chaudhary L, Sindhu A, Kumar M, Kumar R, Saini M 2010. Estimation of genetic divergence among some cotton varieties by RAPD analysis. In Journal of Plant Breeding and Crop Science, 2:39-43.

Doyle JJ, Doyle JL 1987. A rapid DNA isolation procedure for small quantities of fresh leaf tissues. Phytochemical Bulletin, 19(1): 11-15.

Erkılınç A, Karaca M 2005. Assessment of Genetic Variation in Some Cotton Varieties (Gossypium hirsutum L.) Grown in Turkey Using Microsatellite. Akdeniz Üniversitesi Ziraat Fakültesi Dergisi, 18(2): 201-206.

FAO 2018. Food and Agriculture Organization of the United Nations. http://www.fao.org Erişim Tarihi: 27.12.2018

Gorman MB, Kiang YT 1977. Variety-specific electrophoretic variants of four soybean enzymes. Crop Science 17: 963-965

Hamrick JL, Godt MJW, Murawski DA, Loveless MD 1991. Correlations between species traits and allozyme diversity: implications for conservation biology. In: Genetic and conservation of rare plants (Falk DA and Holsinger KE, eds.). Oxford University Press, New York, 75-86.

Hussein EHA, Mohamed AA, Attia S, Adawy SS 2006. Molecular characterization and genetic relationships among cotton genotypes 1- RAPD, ISSR and SSR analysis. Arab Journal of Biotechnology, 9: 313-328.

Kwon YS, Ryu TH, Kim CH, Song ICH, Kim KM 2004. A Comparative Study of the RAPD and SSR Markers in Establishing a Genetic Relationship of the Various Types of Cucurbita. Korean Journal of Genetics, 26 (2): 115-122.

Liu B, Wendel JF 2001. Intersimple sequence repeat (ISSR) polymorphisms as a genetic marker system in cotton. Molecular Ecology Notes, 1(3): 205-208.

Mert, M., 2009. Lif Bitkileri. Nobel Yayın Dağıtım, 1446, 278 s, Ankara.

Mignouna HD, Abanf MM, Fagbemi SA 2003. A Comparative Assessment of molecular marker assays (AFLP, RAPD and SSR) for White yam (Dioscirea rotundata Poir )germ plasm characterisation. Annals of Applied Biology, 142 :269-276.

Nei M 1972. Genetic distance between populations. American Naturalist, 106: 283-292

Nei M, Li WH 1979. Mathematical model for studying variation in terms of restriction endonucleases. Proc. Nat. Acad. Sci., 76: 5269-5273.

Peirce LC, Brewbaker JL 1973. Applications of 
isozyme analysis in horticultural science. Hort. Science, 8: 17-22

Pillay M, Myers GO 1999. Genetic diversity in cotton assessed by variation in ribosomal RNA genes and AFLP markers. Crop Science, November-December. 39:1881-1886.

Rana MK, Bhat KV 2004. A Comparison of AFLP and RAPD Markers for Genetic Diversity and Cultivar Identification in Cotton. J. Plant Biochemistry \& Biotechnology, 13: 19-24.

Reinisch AJ, Dong JM, Brubaker CL, Stelly DM, Wendel JF, Paterson AH 1994. A detailed RFLP map of cotton, Gossypium hirsutum x Gossypium barbadense: chromosome organization and evolution in a disomic polyploid genome. Genetics, 138:829-847.

Sammour RH 1991. Using electrophoretic techniques in varietal identification, biosystematic analysis, phylogenetic relations and genetic resources management. J. Islamic Acad. Sci., 4: 221-226.

Tanksley SD, Young ND, Peterson AH, Bonierbale MW 1989. RFLP mapping in plant breeding:new tools for old sciences. Biotechnology, 7:257-264.

TTSM 2018. Tohumluk Tescil ve Sertifikasyon Merkez Müdürlüğü. http://www.ttsm.gov.tr Erişim Tarihi: 27.12.2018

TÜİK 2018. Türkiye İstatistik Kurumu. http://www.tuik.gov.tr Erişim Tarihi: 27.12.2018

Williams JGK, Kubelik AR, Livak KJ, Rafalski JA, Tingey SV 1990. DNA polymorphisms amplified by arbitrary primers are useful as genetic markers. Nucleic Acids Res., 18: 6531-6535.

Zietkiewicz E, Rafalski A, Labuda D 1994. Genome fingerprinting by simple sequence repeat (SSR)anchored polymerase chain reaction amplification. Genomics, 20(2):176-183 